\title{
Metabolism-Related Proteins Are Differentially Expressed according to the Molecular Subtype of Invasive Breast Cancer Defined by Surrogate Immunohistochemistry
}

\author{
Junjeong Choi ${ }^{\mathrm{a}}$ Woo-Hee Jung ${ }^{\mathrm{b}}$ Ja Seung Koo ${ }^{\mathrm{b}}$ \\ a Department of Pathology, Yonsei University, Wonju College of Medicine, Wonju, and b Department of Pathology, \\ Yonsei University Health System, Seoul, South Korea
}

\section{Key Words}

Aerobic glycolysis $\cdot$ Breast cancer $\cdot$ CAIX $\cdot$ Glut-1

\begin{abstract}
Objective: The purpose of this study was to investigate the expression of metabolism-related proteins such as Glut-1 and carbonic anhydrase IX (CAIX) according to breast cancer molecular subtype. Methods: We generated a tissue microarray of 276 breast cancer patients and performed immunohistochemical staining for known metabolism-related proteins, which were evaluated according to the molecular subtype. Results: The expression of IGF-1, MIF, and HIF-1 $\alpha$ was correlated with the HER-2 type $(p<0.05)$. Glut-1 overexpression and CAIX expression were associated with TNBC type, especially with basal-like type, high histologic grade, estrogen receptor negativity, and progesterone receptor negativity $(p<0.05)$. The expression of Glut-1 and CAIX was correlated with statistical significance $(p<0.001)$. Conclusion: We identified different patterns of expression of metabolismrelated proteins according to the molecular subtypes of breast cancer defined by surrogate immunohistochemistry. Increased expression of HIF-1 $\alpha$, IGF-1, and MIF was noted in HER-2 type breast cancer and increased expression of Glut-1
\end{abstract}

and CAIX was noted in TNBC type breast cancer, especially in the basal-like subtype, which exhibited a glycolytic and acid-resistant tumor phenotype.

Copyright $\odot 2012$ S. Karger AG, Basel

\section{Introduction}

Differences in the metabolism of neoplastic cells and normal cells originate from the fact that tumor cells gain energy not by aerobic phosphorylation from the tricarboxylic acid cycle but rather by aerobic glycolysis, a phenomenon known as Warburg's effect [1]. Several possible explanations for the selective biochemical processes of neoplastic cells have been suggested. In order to adapt to hypoxic microenvironments caused by oxygen deprivation as a result of the uncontrollable proliferation of neoplastic cells, tumor cells employ the mechanism that consumes the least oxygen, aerobic glycolysis. In addition, the genes that activate aerobic glycolysis may be subjected to different regulating mechanisms in tumors, resulting in altered expression $[2,3]$. As a key process in aerobic glycolysis, glucose uptake into the tumor cells is increased and Glut-1 acts as a glucose transporter (fig. 1).

\begin{tabular}{ll}
\hline KARGER & ( ) 2012 S. Karger AG, Basel \\
Fax +4161306 1234 & \\
$\begin{array}{l}\text { E-Mail karger@karger.ch } \\
\text { www.karger.com }\end{array}$ & $\begin{array}{l}\text { Accessible online at: } \\
\text { www.karger.com/pat }\end{array}$
\end{tabular}


Fig. 1. Overview of aerobic glycolysis-related proteins in cancer cell metabolism. Several factors, including hypoxia, growth factor (IGF-1), and oncogene activation (cmyc), activate HIF- $1 \alpha$, leading to increases in the expression of Glut-1 in the cell membrane, the uptake of glucose, and the generation of lactate by glycolysis. The generation of lactate results in intracellular acidosis. The expression of CAIX increases to prevent intracellular acidosis, and the expression of PDK1 increases to decrease mitochondrial respiration. In addition, the expression of MIF increases to prevent cell senescence induced by reactive oxygen species.

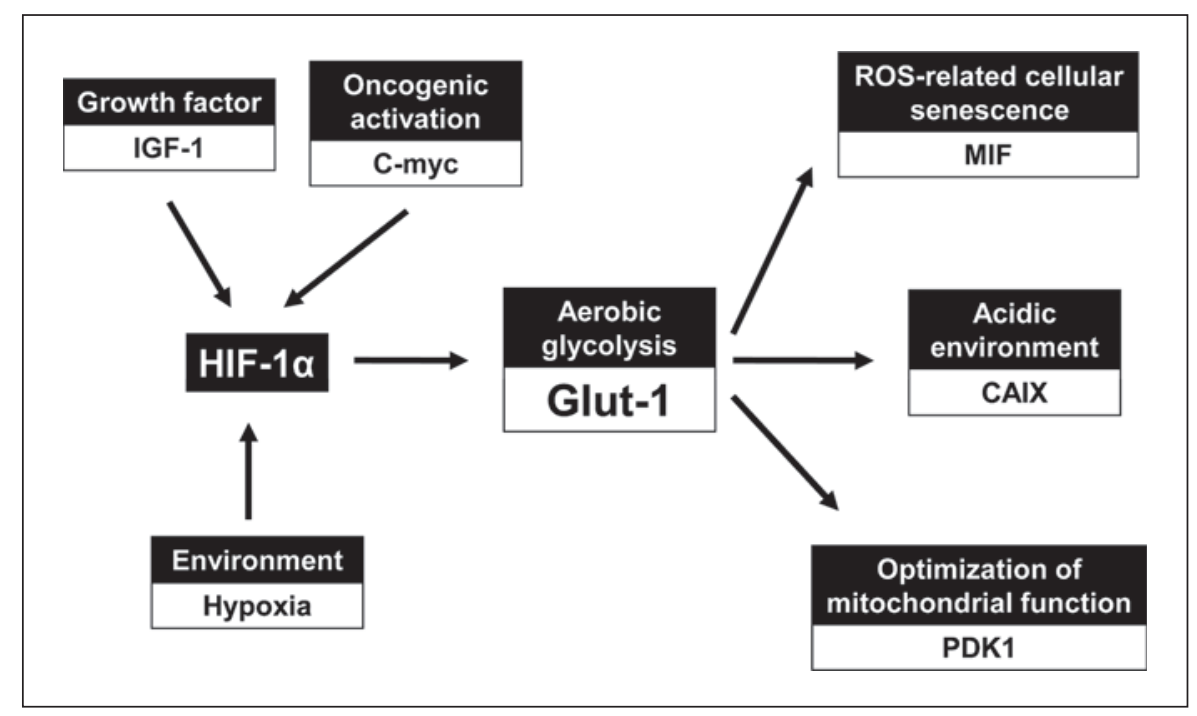

Increased expression of Glut-1 results in an increase in glucose uptake into cells and in generation of lactate by glycolysis, leading to intracellular acidosis. To prevent acidosis, the expression of carbonic anhydrase IX (CAIX) is increased, as is the expression of pyruvate dehydrogenase kinase 1 (PDK1) in order to suppress mitochondrial respiration. In addition, the expression of macrophage migration inhibitory factor (MIF) is increased to prevent cellular senescence induced by reactive oxygen species [4-11].

Overexpression of Glut-1 during the neoplastic process has been reported in human carcinomas. Overexpression of Glut-1 has been shown to be associated with high-grade tumors, poorly differentiated tumors, tumor invasion, and tumor metastasis [12-15]. Glut-1 overexpression also has been shown to be associated with poor prognosis in oral squamous cell carcinoma [16], nonsmall cell lung cancer [17], pulmonary adenocarcinoma [18], and thyroid cancer [19], as well as with metastasis in gastric cancer [20] and cervical cancer. [21].

In the previous gene expression profile study, breast carcinomas were classified into the following five molecular subtypes: luminal A, luminal B, HER-2, normal breast-like, and basal-like [22]. Apart from these five molecular subtypes, estrogen receptor (ER)-, progesterone receptor (PR)-, and HER-2-negative carcinomas were defined clinically as triple-negative breast cancer (TNBC) [23]. Previous studies regarding the role of metabolismrelated proteins in breast cancer have shown that overexpression of Glut-1 is correlated with high grade [24, 25], proliferative activity [26, 27], poor differentiation [27], and poor prognosis [28], and overexpression of CAIX is correlated with high grade [29], metastatic breast cancer cell lines [30], and poor prognosis [31-33]. Accordingly, since the HER-2 type and basal-like type of breast cancer exhibit high-grade histology, increased proliferative activity, and areas of geographic tumor necrosis, increased expression of metabolism-related proteins in these specific types of breast cancer is to be expected [34-39]. However, a limited number of studies regarding the expression of metabolism-related proteins according to the molecular subtypes of breast cancer have been conducted [40]. The purpose of this study was to investigate the expression of metabolism-related proteins such as Glut-1 and CAIX according to breast carcinoma subtypes and to determine the implications of these expression patterns.

\section{Materials and Methods}

\section{Patient Selection}

From the Department of Pathology at Severance Hospital, we retrieved tissue samples collected from patients with invasive ductal breast carcinoma that were archived between January 2000 and December 2001. This study was approved by the Institutional Review Board of Severance Hospital. Formalin-fixed and paraffin-embedded tissue specimens from 276 cases of primary breast cancer were included. All archival hematoxylin and eosin (H\&E)-stained slides for each case were reviewed by two pathologists (J.S. Koo and J. Choi). Histological grade was assessed using the Nottingham grading system [41]. The clinical parameters that were evaluated for each tumor included patient age at initial diagnosis, lymph node status, local recurrence, systemic recurrence, and patient survival. 
Table 1. Source, clone, and dilution of antibodies

\begin{tabular}{llll}
\hline Antibody & Clone & Dilution & Company \\
\hline $\begin{array}{l}\text { Aerobic glycolysis } \\
\text { IGF-1 }\end{array}$ & & \\
c-myc (phospho Ser62) & Polyclonal & $1: 100$ & Abcam, Cambridge, UK \\
HIF-1 $\alpha$ & Polyclonal & $1: 100$ & Abcam \\
Glut-1 & EP1215Y & $1: 100$ & Biocare, Yorba Linda, Calif., USA \\
MIF & SPM498 & $1: 200$ & Abcam \\
CAIX & Polyclonal & $1: 100$ & Abcam \\
PDK1 & Polyclonal & $1: 100$ & Abcam \\
Molecular subtype & Polyclonal & $1: 100$ & Abcam \\
ER & & & \\
PR & SP1 & $1: 100$ & Thermo Scientific, USA \\
HER-2 & PgR & $1: 50$ & DAKO, Glostrup, Denmark \\
CK5/6 & Polyclonal & $1: 1500$ & DAKO \\
EGFR & D5/16B4 & $1: 50$ & DAKO \\
\hline
\end{tabular}

Tissue Microarray

A representative area was selected on each $\mathrm{H} \& \mathrm{E}$-stained slide and a corresponding spot was marked on the surface of the paraffin block. Using a biopsy needle, the selected area was punched out and a $3-\mathrm{mm}$ tissue core was placed into a $6 \times 5$ recipient block. The tissue of the invasive tumor was extracted. Two tissue cores were extracted to minimize extraction bias. Each tissue core was assigned a unique tissue microarray location number that was linked to a database containing other clinicopathologic data.

\section{Immunohistochemistry}

The antibodies used for immunohistochemistry in this study are shown in table 1 . All immunostaining was performed using formalin-fixed, paraffin-embedded tissue sections. Briefly, 5 - $\mu \mathrm{m}$-thick sections were obtained with a microtome, transferred onto adhesive slides, and dried at $62^{\circ} \mathrm{C}$ for $30 \mathrm{~min}$. After incubation with primary antibodies, immunodetection was performed with biotinylated anti-mouse immunoglobulin, followed by peroxidase-labeled streptavidin using a labeled streptavidin biotin kit with 3,3'-diaminobenzidine chromogen as the substrate. The primary antibody incubation step was omitted in the negative control. Slides were counterstained with Harris hematoxylin.

\section{Interpretation of Immunohistochemical Staining}

All immunohistochemical markers were assessed by light microscopy. A cut-off value of $1 \%$ or more of positively stained nuclei was used to define ER and PR positivity [42]. HER-2 staining was analyzed according to the American Society of Clinical Oncology (ASCO)/College of American Pathologists (CAP) guidelines using the following categories: $0=$ no immunostaining; $1+=$ weak incomplete membranous staining in less than $10 \%$ of tumor cells; $2+=$ complete membranous staining, either uniform or weak in at least $10 \%$ of tumor cells, and $3+=$ uniformly intense membranous staining in at least $30 \%$ of tumor cells. HER-2 immunostaining was considered positive when strong $\left(3^{+}\right)$membranous staining was observed, whereas cases with $0-1+$ staining were regarded as negative [43]. Cases with 2+ HER-2 expression were evaluated for HER-2 amplification by fluorescent in situ hybridization (FISH). The immunostained slides were scored according to the percentage or intensity of tumor cells exhibiting nuclear (c-myc and HIF- $\alpha$ ), cytoplasmic [insulin-like growth factor (IGF)-1, c-myc, Glut-1, MIF, CAIX, PDK1, HIF- $\alpha$, and cytokeratin (CK) 5/6], and membranous epidermal growth factor receptor (EGFR) staining. Immunohistochemical stain results for EGFR, PDK1, c-myc, CAIX, and IGF-1 were evaluated based on the intensity of expression ( 0 = negative, $1=$ weak, $2=$ moderate, and 3 = strong). Moderate or intense staining was considered positive. Results for HIF- $\alpha$, MIF, and CK5/6 were considered positive when more than $10 \%$ of the tumor cells were stained. The results for Glut-1 were scored according to the percentage of tumor cells with Glut-1 positivity as follows: low (less than 50\%) and high (more than $50 \%)$.

\section{FISH Analysis}

Invasive tumors were examined on $\mathrm{H} \& \mathrm{E}$-stained slides and FISH was subsequently performed on the tested tumor using a PathVysion HER-2 DNA Probe Kit (Vysis, Downers Grove, Ill., USA) according to the manufacturer's instructions. The HER-2 gene copy number on the slides was evaluated using an epifluorescence microscope (Olympus, Tokyo, Japan). At least 60 tumor cell nuclei in three separate regions were investigated for HER-2 and chromosome 17 signals. HER-2 gene amplification was determined according to ASCO/CAP guidelines [43]. An absolute HER-2 gene copy number lower than 4 or an HER-2 gene/chromosome 17 copy number ratio (HER-2 /Chr17 ratio) of less than 1.8 was considered HER-2 negative. An absolute HER-2 copy number between 4 and 6 or an HER-2/Chr17 ratio between 1.8 and 2.2 was considered HER-2 equivocal. An absolute HER-2 copy number greater than 6 or an HER-2/Chr17 ratio higher than 2.2 was considered HER-2 positive.

Tumor Phenotype Classification Using Surrogate Markers

In this study, we classified breast cancer phenotypes according to immunohistochemistry results for ER, PR, HER-2, and FISH 
Table 2. Clinicopathologic characteristics of patients according to breast cancer phenotype

\begin{tabular}{|c|c|c|c|c|c|c|}
\hline Parameter & $\begin{array}{l}\text { Total } \\
(\mathrm{n}=276)\end{array}$ & $\begin{array}{l}\text { TNBC } \\
(n=97)\end{array}$ & $\begin{array}{l}\text { HER-2 type } \\
(\mathrm{n}=25)\end{array}$ & $\begin{array}{l}\text { Luminal B } \\
(\mathrm{n}=33)\end{array}$ & $\begin{array}{l}\text { Luminal A } \\
(\mathrm{n}=121)\end{array}$ & $\mathrm{p}$ value \\
\hline Mean age $( \pm S D)$, years & $49.0 \pm 10.6$ & $47.5 \pm 12.4$ & $50.9 \pm 10.2$ & $47.3 \pm 8.9$ & $50.2 \pm 9.4$ & 0.175 \\
\hline \multicolumn{6}{|l|}{ Histologic grade } & \multirow[t]{4}{*}{$<0.001$} \\
\hline I & $33(12.0)$ & $4(4.1)$ & 0 & $1(3.0)$ & $28(23.1)$ & \\
\hline II & $147(53.3)$ & $35(36.1)$ & $14(56.0)$ & $19(57.6)$ & $79(65.3)$ & \\
\hline III & $96(34.8)$ & $58(59.8)$ & $11(44.0)$ & $13(39.4)$ & $14(11.6)$ & \\
\hline \multicolumn{6}{|l|}{ Tumor stage } & \multirow[t]{4}{*}{0.002} \\
\hline $\mathrm{T} 1$ & $123(44.6)$ & $30(30.9)$ & $10(40.0)$ & $22(66.7)$ & $61(50.4)$ & \\
\hline $\mathrm{T} 2$ & $149(54.0)$ & $63(64.9)$ & $15(60.0)$ & $11(33.3)$ & $60(49.6)$ & \\
\hline T3 & $4(1.4)$ & $4(4.1)$ & 0 & 0 & 0 & \\
\hline \multicolumn{6}{|l|}{ Nodal stage } & \multirow[t]{5}{*}{0.792} \\
\hline N0 & $153(55.4)$ & $56(20.3)$ & $15(60.0)$ & $21(63.6)$ & $61(50.4)$ & \\
\hline N1 & $78(28.3)$ & $27(27.8)$ & $5(20.0)$ & $9(27.3)$ & $37(30.6)$ & \\
\hline $\mathrm{N} 2$ & $28(10.1)$ & $9(9.3)$ & $4(16.0)$ & $1(3.0)$ & $14(11.6)$ & \\
\hline N3 & $17(6.2)$ & $5(5.2)$ & $1(4.0)$ & $2(6.1)$ & $9(7.4)$ & \\
\hline Tumor recurrence & $27(9.8)$ & $17(17.5)$ & $5(20.0)$ & $1(3.0)$ & $4(3.3)$ & $<0.001$ \\
\hline Patient deaths & $23(8.3)$ & $15(15.5)$ & $4(16.0)$ & $1(3.0)$ & $3(2.5)$ & 0.002 \\
\hline \multicolumn{7}{|l|}{ Mean duration of clinical } \\
\hline follow-up ( $\pm \mathrm{SD})$, months & $67.0 \pm 17.6$ & $67.5 \pm 24.8$ & $61.5 \pm 16.8$ & $68.5 \pm 11.5$ & $67.4 \pm 11.2$ & 0.430 \\
\hline
\end{tabular}

Values in parentheses are percents.

as follows: luminal A type, ER or/and PR positive and HER-2 negative; luminal B type, ER or/and PR positive and HER-2 overexpressed and/or amplified; HER-2 overexpression type, ER and PR negative and HER-2 overexpressed and/or amplified, and TNBC type, ER, PR, and HER-2 negative. The TNBC type was sub-classified into basal-like (CK5/6 positive and/or EGFR positive) or non-basal-like types (CK5/6 and EGFR negative).

\section{Statistical Analysis}

Data was analyzed using SPSS for Windows, version 12.0 (SPSS Inc., Chicago, Ill., USA). For the determination of statistical significance, Student's t test and Fisher's exact test were used for continuous and categorical variables, respectively. $\mathrm{p}<0.05$ was considered statistically significant. Kaplan-Meier survival curves and log-rank statistics were employed to evaluate the time to tumor recurrence. Multivariate regression analysis was performed using the Cox proportional hazards model.

\section{Results}

\section{Patient Characteristics}

The clinicopathologic characteristics of 276 patients, which comprised 97 (35.1\%) cases of TNBC, 25 (9.1\%) cases of the HER-2 type, 33 (12.0\%) cases of luminal B, and $121(43.8 \%)$ cases of the luminal A type, are summarized in table 2. The TNBC and HER-2 types had higher histo- logic grades $(p<0.001)$, higher tumor stage $(p=0.002)$, higher tumor recurrence rates $(\mathrm{p}<0.001)$, and a higher number of patient deaths $(\mathrm{p}=0.002)$.

\section{Metabolic Signature according to Molecular Subtype of Breast Cancer}

Metabolism-related protein expression according to the molecular subtype of breast cancer is summarized in table 3 and figure 2. The HER-2 type showed higher rates of positivity for IGF-1 ( $\mathrm{p}=0.020), \mathrm{HIF}-1 \alpha(\mathrm{p}=0.005)$, and MIF ( $\mathrm{p}<0.001)$. The TNBC type showed higher rates of Glut-1 overexpression and positive expression of CAIX $(\mathrm{p}<0.001$ and $\mathrm{p}=0.012$, respectively), whereas the rate of CAIX expression in the tumor stroma was the lowest $(\mathrm{p}=0.012)$. The luminal A type had the lowest rates of expression of IGF-1, HIF-1 $\alpha$, and Glut-1. The patterns of metabolism-related protein expression in the basal-like type and non-basal-like type TNBCs are summarized in table 4 . A total of 33 cases of the basal type (34.0\%) and 64 cases of the non-basal-like type (66.6\%) were studied. The rates of high Glut-1 expression and CAIX positivity were higher in the basal-like type compared with the non-basal-like type $(\mathrm{p}=0.010$ and $\mathrm{p}<0.001$, respectively). 
Table 3. Immunohistochemical characteristics of cancer cell metabolism-related proteins according to breast cancer phenotype

\begin{tabular}{|c|c|c|c|c|c|c|}
\hline \multirow[t]{2}{*}{ Antibody } & \multirow{2}{*}{$\begin{array}{l}\text { Total } \\
(\mathrm{n}=276)\end{array}$} & \multicolumn{4}{|c|}{ Tumor phenotype (mean $\pm \mathrm{SD})$} & \multirow[t]{2}{*}{$\mathrm{p}$ value } \\
\hline & & $\begin{array}{l}\text { TNBC } \\
(\mathrm{n}=97)\end{array}$ & $\begin{array}{l}\text { HER-2 } \\
(\mathrm{n}=25)\end{array}$ & $\begin{array}{l}\text { Luminal B } \\
(\mathrm{n}=33)\end{array}$ & $\begin{array}{l}\text { Luminal A } \\
(\mathrm{n}=121)\end{array}$ & \\
\hline c-myc & & & & & & 0.207 \\
\hline Negative & $160(58.0)$ & $62(63.9)$ & $17(68.0)$ & $16(48.5)$ & $65(53.7)$ & \\
\hline Positive & $116(62.0)$ & $35(36.1)$ & $8(32.0)$ & $17(51.5)$ & $56(46.3)$ & \\
\hline IGF-1 & & & & & & 0.020 \\
\hline Negative & $263(95.3)$ & $92(94.8)$ & $21(84.0)$ & $31(93.9)$ & $119(98.3)$ & \\
\hline Positive & $13(4.7)$ & $5(5.2)$ & $4(16.0)$ & $2(6.1)$ & $2(1.7)$ & \\
\hline $\mathrm{HIF}-1 \alpha$ & & & & & & 0.005 \\
\hline Negative & $263(95.3)$ & $90(92.8)$ & $21(84.0)$ & $32(97.0)$ & $120(99.2)$ & \\
\hline Positive & $13(4.7)$ & $7(7.2)$ & $4(16.0)$ & $1(3.0)$ & $1(0.8)$ & \\
\hline Glut-1 & & & & & & $<0.001$ \\
\hline Low & $244(88.4)$ & $69(71.1)$ & $23(92.0)$ & $32(97.0)$ & $120(99.2)$ & \\
\hline High & $32(11.6)$ & $28(28.9)$ & $2(8.0)$ & $1(3.0)$ & $1(0.8)$ & \\
\hline MIF & & & & & & $<0.001$ \\
\hline Negative & $240(87.0)$ & $89(32.2)$ & $17(68.0)$ & $24(72.7)$ & 110 (90.9) & \\
\hline Positive & $36(13.0)$ & $8(8.2)$ & $8(32.0)$ & $9(27.3)$ & $11(9.1)$ & \\
\hline CAIX & & & & & & 0.012 \\
\hline Negative & $186(67.4)$ & $56(57.7)$ & $16(64.0)$ & 29 (87.9) & $85(70.2)$ & \\
\hline Positive & $90(32.6)$ & $41(42.3)$ & $9(36.0)$ & $4(12.1)$ & $36(29.8)$ & \\
\hline $\begin{array}{l}\text { CAIX in the } \\
\text { tumor stroma }\end{array}$ & & & & & & 0.012 \\
\hline Negative & $242(87.7)$ & $92(94.8)$ & $18(72.0)$ & $28(84.8)$ & 104 (85.9) & \\
\hline Positive & $34(12.3)$ & $5(5.2)$ & $7(28.0)$ & $5(15.2)$ & $17(14.1)$ & \\
\hline PDK1 & & & & & & 0.522 \\
\hline Negative & $123(44.6)$ & $48(49.5)$ & $12(48.0)$ & $15(45.5)$ & $48(39.7)$ & \\
\hline Positive & $153(55.4)$ & $49(50.5)$ & $13(52.0)$ & $18(54.5)$ & $73(60.3)$ & \\
\hline
\end{tabular}

Values in parentheses are percents.

Correlations between the Expression of

Metabolism-Related Proteins and Clinicopathologic

Factors

The correlations between the expression of metabolism-related proteins and clinicopathologic factors are summarized in table 5. The expression of c-myc was correlated with ER positivity $(\mathrm{p}=0.037)$ and PR positivity $(\mathrm{p}=0.032)$, and the expression of IGF-1 was correlated with high histologic grade $(\mathrm{p}=0.038)$, ER negativity $(\mathrm{p}=$ $0.019)$, and HER-2 positivity ( $\mathrm{p}=0.023)$. The expression of HIF- $1 \alpha$ was correlated with high histologic grade $(\mathrm{p}=$ $0.038)$, high $\mathrm{T}$ stage $(\mathrm{p}=0.006)$, lymph node metastasis $(\mathrm{p}=0.003)$, ER negativity $(\mathrm{p}=0.004)$, and PR negativity $(\mathrm{p}=0.032)$, and high Glut-1 expression was correlated with high histologic grade $(\mathrm{p}<0.001)$, absence of lymph node metastasis $(\mathrm{p}=0.006)$, ER negativity $(\mathrm{p}<0.001)$, and PR negativity $(\mathrm{p}<0.001)$. The expression of MIF was cor- related with HER-2 positivity ( $\mathrm{p}<0.001)$, and the expression of CAIX was correlated with high histologic grade $(\mathrm{p}=0.019)$ and ER negativity $(\mathrm{p}=0.008)$.

\section{The Impact of Metabolism-Related Proteins on}

\section{Disease-Free Survival and Overall Survival}

The relationships between the expression of metabolism-related proteins and disease-free survival (DFS) and overall survival (OS) are summarized in table 6. HIF-1 $\alpha$ positivity was correlated with a shorter DFS and OS ( $\mathrm{p}<$ 0.001), and high Glut-1 expression was correlated with a shorter DFS $(p=0.028)$. Multivariate Cox regression analysis was used to identify clinicopathologic and immunohistochemical parameters affecting patient survival. Parameters associated with a shorter DFS included younger age ( $\leq 35$ vs. $>35, \mathrm{p}=0.014, \mathrm{OR}=3.285,95 \% \mathrm{CI}$ $1.268-8.501$ ), high $\mathrm{T}$ stage ( $\mathrm{T} 1$ vs. $\mathrm{T} 2-3, \mathrm{p}=0.018, \mathrm{OR}=$ 


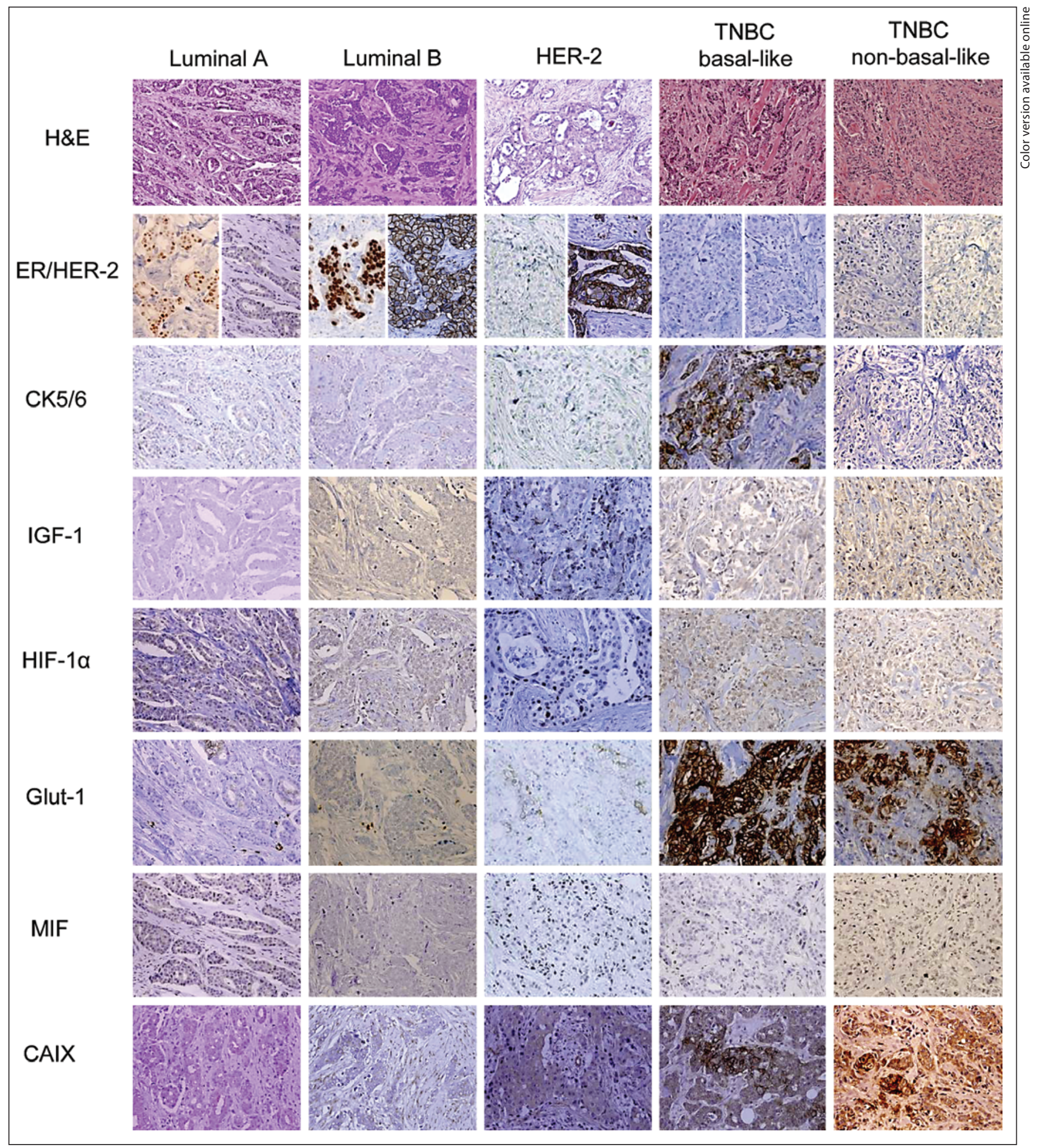

Fig. 2. Expression of metabolism-related proteins according to molecular subtype. The HER-2 type expresses IGF-1, HIF-1 $\alpha$, and MIF. The TNBC type expresses high levels of CAIX and Glut-1, particularly in the basallike subtype. 
Table 4. Clinicopathologic and immunohistochemical characteristics of cancer cell metabolism-related proteins in TNBC

\begin{tabular}{|c|c|c|c|}
\hline & \multicolumn{2}{|l|}{ TNBC } & \multirow{2}{*}{$\begin{array}{l}\mathrm{p} \\
\text { value }\end{array}$} \\
\hline & $\begin{array}{l}\text { basal-like } \\
(\mathrm{n}=33)\end{array}$ & $\begin{array}{l}\text { non-basal-like } \\
(\mathrm{n}=64)\end{array}$ & \\
\hline \multicolumn{4}{|l|}{ Clinicopathologic parameters } \\
\hline Mean age $( \pm \mathrm{SD})$, years & $47.3 \pm 11.9$ & $47.6 \pm 12.8$ & 0.918 \\
\hline Histologic grade & & & 0.085 \\
\hline I & $2(6.1)$ & $2(3.1)$ & \\
\hline II & $7(21.2)$ & $28(43.8)$ & \\
\hline III & $24(72.7)$ & $34(53.1)$ & \\
\hline Tumor stage & & & 0.789 \\
\hline $\mathrm{T} 1$ & $10(30.3)$ & $20(31.3)$ & \\
\hline $\mathrm{T} 2$ & $21(63.6)$ & $42(65.6)$ & \\
\hline T3 & $2(6.1)$ & $2(3.1)$ & \\
\hline Nodal stage & & & 0.436 \\
\hline N0 & $19(57.6)$ & $37(57.8)$ & \\
\hline N1 & $7(21.2)$ & $20(31.2)$ & \\
\hline $\mathrm{N} 2$ & $5(15.2)$ & $4(6.3)$ & \\
\hline N3 & $2(6.1)$ & $3(4.7)$ & \\
\hline Tumor recurrence & $7(21.2)$ & $10(15.6)$ & 0.471 \\
\hline Patient deaths & $7(21.2)$ & $8(12.5)$ & 0.246 \\
\hline $\begin{array}{l}\text { Mean duration of clinical } \\
\text { follow-up }( \pm S D) \\
\text { months }\end{array}$ & $67.3 \pm 25.0$ & $67.5 \pm 24.9$ & 0.967 \\
\hline \multicolumn{4}{|c|}{ Immunohistochemical parameters } \\
\hline $\mathrm{c}-\mathrm{myc}$ & & & 0.626 \\
\hline Negative & $20(60.6)$ & $42(65.6)$ & \\
\hline Positive & $13(39.4)$ & $22(34.4)$ & \\
\hline IGF-1 & & & 0.772 \\
\hline Negative & $31(93.9)$ & $61(95.3)$ & \\
\hline Positive & $2(6.1)$ & $3(4.7)$ & \\
\hline $\mathrm{HIF}-1 \alpha$ & & & 0.180 \\
\hline Negative & $29(87.9)$ & $61(95.3)$ & \\
\hline Positive & $4(12.1)$ & $3(4.7)$ & \\
\hline Glut-1 & & & 0.010 \\
\hline Low & $18(54.5)$ & $51(79.7)$ & \\
\hline High & $15(45.5)$ & $13(20.3)$ & \\
\hline MIF & & & 0.574 \\
\hline Negative & $31(93.9)$ & $58(90.6)$ & \\
\hline Positive & $2(6.1)$ & $6(9.3)$ & \\
\hline CAIX & & & 0.000 \\
\hline Negative & $11(33.3)$ & $45(70.3)$ & \\
\hline Positive & $22(66.7)$ & $19(29.7)$ & \\
\hline CAIX in tumor the stroma & & & 0.772 \\
\hline Negative & $31(93.9)$ & $61(95.3)$ & \\
\hline Positive & $2(6.1)$ & $3(4.7)$ & \\
\hline PDK1 & & & 0.474 \\
\hline Negative & $18(54.5)$ & $30(46.9)$ & \\
\hline Positive & $15(45.5)$ & $34(53.1)$ & \\
\hline
\end{tabular}

Values in parentheses are percents.
$3.285,95 \%$ CI $1.250-10.951)$, HIF- $1 \alpha$ positivity $(\mathrm{p}=0.002$, $\mathrm{OR}=5.208,95 \%$ CI 1.835-14.778), and high Glut-1 expression $(\mathrm{p}=0.049, \mathrm{OR}=2.574,95 \%$ CI $1.004-6.601)$. Parameters associated with shorter OS were younger age ( $\leq 35$ vs. $>35, \mathrm{p}=0.022$, OR $=3.338,95 \%$ CI $1.188-9.376$ ), high T stage ( $\mathrm{T} 1$ vs. $\mathrm{T} 2-3, \mathrm{p}=0.016, \mathrm{OR}=4.565,95 \% \mathrm{CI}$ $1.333-15.638)$, and HIF- $1 \alpha$ positivity $(\mathrm{p}=0.009$, OR $=$ $4.538,95 \%$ CI 1.459-14.114).

\section{Discussion}

We investigated the expression of cancer cell metabolism-related proteins according to the molecular subtypes of breast cancer defined by surrogate immunohistochemistry. The expression of HIF-1 $\alpha$ was associated with the HER-2 subtype ( $\mathrm{p}=0.005)$, a high histologic grade $(\mathrm{p}=0.038)$, a high $\mathrm{T}$ stage $(\mathrm{p}=0.006)$, lymph node metastasis $(p=0.003)$, ER negativity $(p=0.004)$, and PR negativity $(\mathrm{p}=0.032)$, which was consistent with previous results that showed that HIF- $1 \alpha$ is correlated with a high histologic grade, ER negativity, and PR negativity [29, 44].

The association between the expression of HIF- $1 \alpha$ and ER and PR negativity may be explained by several mechanisms. Since it has been reported that hypoxia decreases the expression of hormone receptors [45], it is possible that the expression of HIF-1 $\alpha$ induced by hypoxia results in the loss of hormone receptors. Another explanation is related to the fact that the loss of hormone receptors is a known characteristic of aggressive breast carcinomas exhibiting high proliferative activity, which tends to generate hypoxic areas where the expression of HIF- $1 \alpha$ is increased [29]. However, HIF-1 $\alpha$ seems to have a stronger association with the HER-2 subtype than the TNBC subtype with a high histologic grade, ER negativity, and PR negativity, and this result is supported by the fact that HIF-1 $\alpha$ protein expression is increased via the HER-2 signaling pathway in breast carcinoma [46].

In this study, the expression of HIF-1 $\alpha$ was not strongly associated with HER-2 positivity per se, but it was associated with the HER-2 subtype. This finding suggests that HIF-1 $\alpha$ expression is not associated with the luminal B subtype (ER+, PR+, and HER-2+), although it was associated with the HER-2 subtype (ER-, PR-, and HER-2+). We are unsure of the underlying mechanism for this difference, but it may be because factors other than HER-2 expression status could also affect HIF-1 expression. Previous studies have suggested that the expression patterns of HIF- $1 \alpha$ reflect different mechanisms. It has been reported that perinecrotic or focal patterns of expression 
Table 5. Correlations between the expressions of metabolism-related proteins and clinicopathologic factors

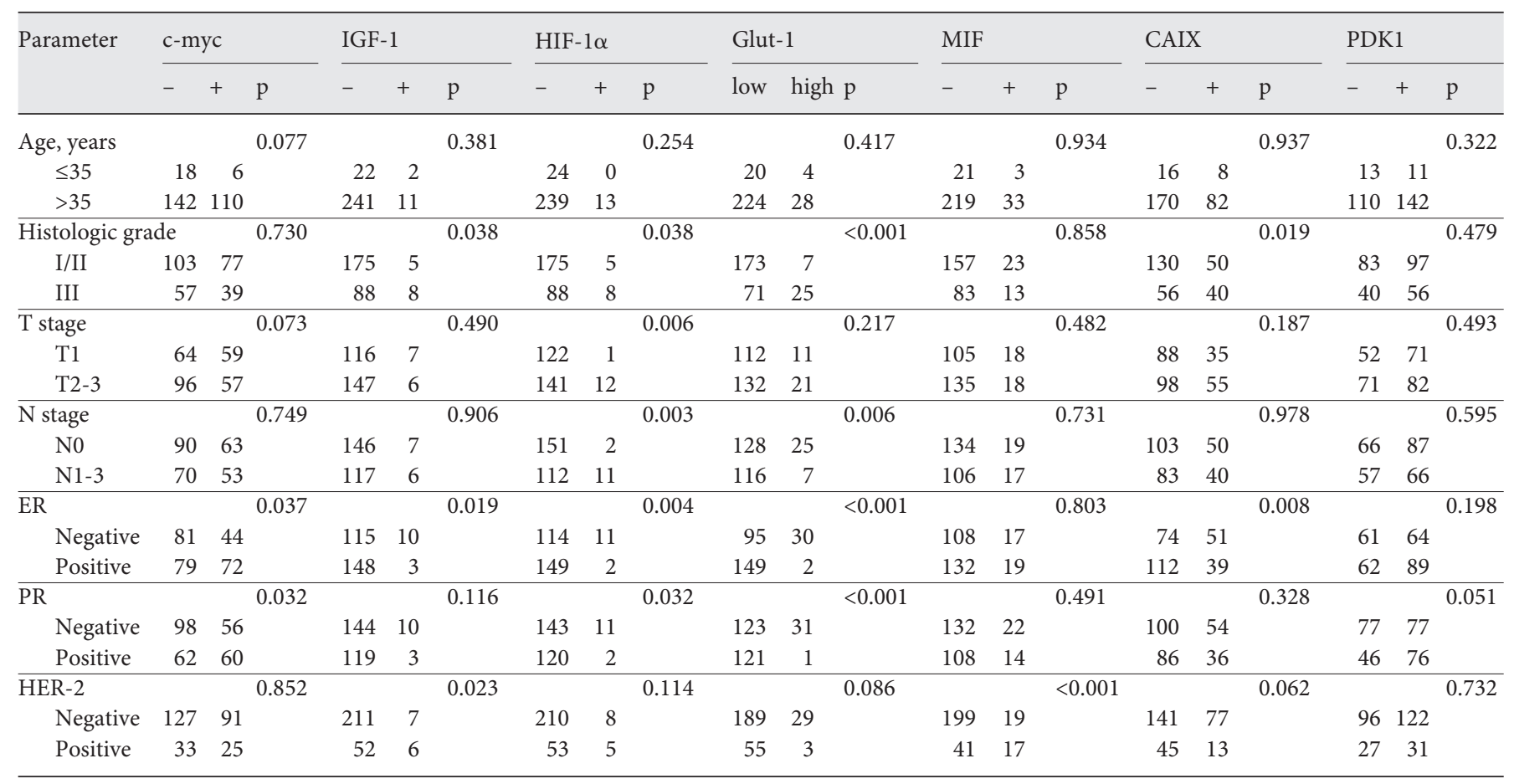

reflect HIF-1 $\alpha$ overexpression induced by severe hypoxia [47] and that diffuse patterns of expression reflect HIF$1 \alpha$ overexpression by HER-2 [46], HIF-1 $\alpha$ gene amplification [48], or mutation [49] rather than hypoxia. In this study, we were unable to compare results directly with previous studies since a diffuse pattern of HIF-1 $\alpha$ expression was not noted in more than $50 \%$ for any tumor.

MIF expression was strongly associated with the HER2 subtype and HER-2 positivity $(\mathrm{p}<0.001)$. A previous study demonstrated a positive correlation between MIF expression and HER-2 expression [50], which was consistent with the results of our study, whereas MIF expression was correlated with ER and PR positivity in another study [51]. Thus, additional research is required to elucidate the role of MIF in breast cancer.

Glut-1 high expression was associated with TNBC type $(\mathrm{p}<0.001)$, high histologic grade $(\mathrm{p}<0.001)$, absence of lymph node metastasis $(\mathrm{p}=0.006)$, ER negativity $(\mathrm{p}<$ $0.001)$, and PR negativity $(\mathrm{p}<0.001)$ in this study. Previous studies have shown that in breast cancer Glut-1 overexpression is associated with high histologic grade, high proliferative activity, poor differentiation, BRCA1-related breast cancer, ER negativity, PR negativity, and the basal-like subtype [24-27, 33, 47, 52], and the results are consistent with those of this study. The expression of
CAIX was associated with TNBC type $(\mathrm{p}=0.012)$, high histologic grade $(\mathrm{p}=0.019)$, and ER negativity $(\mathrm{p}=0.008)$, and these results are consistent with previous studies showing that the expression of CAIX in breast cancer is correlated with a high histologic grade, BRCA1-related breast cancer, ER negativity, PR negativity, and the basallike subtype $[31-33,47]$. The expression of Glut- 1 and that of CAIX were associated with similar parameters, consistent with a previous study that showed a highly positive correlation between Glut1 expression and CAIX expression [30]. The expression of Glut-1 and that of CAIX were closely related in this study ( $\mathrm{p}<0.001$, data not shown).

The expression of HIF- $1 \alpha$ was not related with that of either Glut-1 or CAIX in this study. A previous study using invasive breast cancer tissue was also unable to identify a relationship between the expression of HIF- $1 \alpha$ and Glut-1 or CAIX [30, 40, 53, 54]. Although both Glut-1 and CAIX are known target genes of HIF- $1 \alpha$ as part of the metabolic process, there was no association between HIF$1 \alpha$ and their expression levels. One possible explanation for this lack of association is the difference in the halflives of HIF- $1 \alpha$ and Glut-1/CAIX. HIF- $1 \alpha$ is undetectable a few minutes after re-oxygenation, whereas Glut- 1 and CAIX persist due to their relative stabilities $[54,55]$. Another possible explanation is that the expression of Glut-1 
Table 6. Univariate analysis of metabolism-related proteins in breast cancer and time to DFS and OS by log-rank test

\begin{tabular}{|c|c|c|c|c|c|c|c|}
\hline & \multicolumn{3}{|c|}{ Number of patients } & \multicolumn{2}{|l|}{ DFS } & \multicolumn{2}{|l|}{ OS } \\
\hline & & $\begin{array}{l}\text { tumor recurrence } \\
(\mathrm{n}=27)\end{array}$ & $\begin{array}{l}\text { patient death } \\
(\mathrm{n}=23)\end{array}$ & $\begin{array}{l}\text { mean survival }(95 \% \\
\mathrm{CI}) \text {, months }\end{array}$ & $\mathrm{p}$ & $\begin{array}{l}\text { mean survival ( } 95 \% \\
\mathrm{CI}) \text {, months }\end{array}$ & $\mathrm{p}$ \\
\hline \multicolumn{4}{|l|}{$\mathrm{c}-\mathrm{myc}$} & & \multirow[t]{3}{*}{0.786} & & \multirow[t]{3}{*}{0.368} \\
\hline Positive & 158 & $17(10.8)$ & $16(10.1)$ & $102.6(97.6-107.5)$ & & \multirow{2}{*}{$\begin{array}{r}103.9(99.4-108.4) \\
99.4(96.4-102.4)\end{array}$} & \\
\hline Negative & 116 & $10(8.6)$ & $7(6.0)$ & $96.7(92.6-100.8)$ & & & \\
\hline Positive & 13 & $3(23.1)$ & $3(23.1)$ & $67.8(55.7-80.0)$ & & $68.5(57.2-79.9)$ & \\
\hline \multicolumn{4}{|l|}{ HIF- $1 \alpha$} & & \multirow[t]{3}{*}{$<0.001$} & & \multirow[t]{3}{*}{$<0.001$} \\
\hline Negative & 261 & $22(8.4)$ & $19(7.3)$ & $104.3(100.4-108.2)$ & & $106.2(102.9-109.4)$ & \\
\hline Positive & 13 & $5(38.5)$ & $4(30.8)$ & $65.6(47.9-83.3)$ & & $72.8(58.1-87.5)$ & \\
\hline \multicolumn{4}{|l|}{ Glut-1 } & & 0.028 & $\begin{array}{c}106.1(102.8-109.4) \\
86.8(77.9-95.6)\end{array}$ & 0.053 \\
\hline Positive & 36 & $5(13.9)$ & $5(13.9)$ & $87.7(80.5-95.0)$ & & $88.8(82.5-95.0)$ & \\
\hline \multicolumn{4}{|l|}{ CAIX } & & \multirow[t]{3}{*}{0.271} & & 0.195 \\
\hline Negative & 186 & $16(8.6)$ & $13(7.0)$ & $102.4(97.9-106.9)$ & & $104.6(100.9-108.3)$ & \\
\hline Positive & 88 & $11(12.5)$ & $10(11.4)$ & $101.8(95.5-108.1)$ & & $104.0(98.6-109.4)$ & \\
\hline \multicolumn{4}{|c|}{ CAIX in the tumor stroma } & & \multirow[t]{3}{*}{0.731} & & \multirow[t]{3}{*}{0.985} \\
\hline Negative & 240 & $23(9.6)$ & $20(8.3)$ & $103.1(99.0-107.3)$ & & $105.1(101.5-108.7)$ & \\
\hline Positive & 34 & $4(11.8)$ & $3(8.8)$ & $102.0(93.3-110.7)$ & & $105.4(99.1-111.7)$ & \\
\hline \multicolumn{4}{|l|}{ PDK1 } & & \multirow[t]{3}{*}{0.616} & & \multirow[t]{3}{*}{0.626} \\
\hline Negative & 122 & $14(11.5)$ & $12(9.8)$ & $100.1(94.4-105.7)$ & & $102.6(97.8-107.4)$ & \\
\hline Positive & 152 & $13(8.6)$ & $11(7.2)$ & $104.9(100.5-109.3)$ & & $106.3(102.3-108.6)$ & \\
\hline
\end{tabular}

Values in parentheses are percents unless otherwise stated.

and CAIX may be regulated by mechanisms other than HIF-1 $\alpha$. The expression of Glut-1 may be increased by inhibitors of oxidative phosphorylation such as mitochondrial inhibitors [56]. In addition, CAIX is known to be activated by the phosphatidylinositol-3-kinase (PI3K) pathway [57] and the mitogen-activated protein kinase (MAPK) pathway [58].

Glut-1 and CAIX expression was highest in the TNBC type, which seems to most closely resemble the glycolytic and acid-resistant phenotype. The glycolytic and acid-resistant phenotype exhibits the most powerful adaptive advantage since it uses glycolysis to supply energy to tumors with a high proliferative activity, thereby enabling continuous tumor growth. Active glycolysis results in intracellular acidosis, which usually leads to acid-mediated cell death. However, overexpression of CAIX, such as in the TNBC type, neutralizes the acidic environment and allows the tumor to become acid resistant. CAIX expression was found in the tumor stroma, as previously re- ported $[29,54,59]$. There was a discrepancy between the results of previous studies regarding the expression of CAIX in the tumor stroma and its implication in the prognosis of breast cancer, thus it was not possible to clarify the role of CAIX expression in the stroma of breast cancer in this study.

In this study, the expression of CAIX in the stroma was the lowest in the TNBC subtype, suggesting that the tumor stroma is acid sensitive in spite of the high CAIX expression, enabling tumor cells of the TNBC subtypes to be acid resistant. It has been reported that increased acidity in the tumor stroma enables tumor invasion through degradation of the extracellular matrix [60] and generation of genetic mutations in the cells [61], which may be related to the aggressiveness of the TNBC type. The basal-like subtype of TNBC had higher rates of Glut1 and CAIX expression than the non-basal-like subtype $(\mathrm{p}=0.010$ and $\mathrm{p}<0.001$, respectively) in this study, which is consistent with the results of previous studies that 
showed that the expression of Glut-1 and CAIX is strongly associated with the basal-like subtype $[33,40]$.

Although there is some overlap in their characteristics, TNBC and basal-like breast cancers are not coincident entities. TNBC is a heterogeneous tumor group comprised of the basal-like subtype, the molecular apocrine subtype (HER-2 enriched type), and the claudinlow subtype [62]. The basal-like subtype of TNBC showed a more glycolytic and acid-resistant phenotype than the non-basal-like subtype in this study, and this result may be linked to the more aggressive behavior of tumors showing the basal markers of TNBC.

In conclusion, we identified different expression patterns of metabolism-related proteins according to the molecular subtypes of breast cancer defined by surrogate markers. Increased expression of HIF-1 $\alpha$, IGF-1, and MIF was noted in the HER-2 type, and increased expression of Glut-1 and CAIX was noted in the TNBC type, especially in the basal-like subtype, which had a glycolytic and acid-resistant phenotype.

\section{Acknowledgement}

This research was supported by the Basic Science Research Program through the National Research Foundation of Korea (NRF) funded by the Ministry of Education, Science, and Technology (2012R1A1A1002886).

\section{References}

$>1$ Warburg O: On the origin of cancer cells Science 1956;123:309-314.

2 Gatenby RA, Gillies RJ: Why do cancers have high aerobic glycolysis? Nat Rev Cancer 2004;4:891-899.

- 3 Kim JW, Gao P, Dang CV: Effects of hypoxia on tumor metabolism. Cancer Metastasis Rev 2007;26:291-298.

4 Kim JW, Dang CV: Cancer's molecular sweet tooth and the Warburg effect. Cancer Res 2006;66:8927-8930.

5 Kim JW, Zeller KI, Wang Y, Jegga AG, Aronow BJ, O’Donnell KA, Dang CV: Evaluation of myc E-box phylogenetic footprints in glycolytic genes by chromatin immunoprecipitation assays. Mol Cell Biol 2004;24: 5923-5936.

6 Maity A, Koumenis C: HIF and MIF - a nifty way to delay senescence? Genes Dev 2006; 20:3337-3341.

-7 Osthus RC, Shim H, Kim S, Li Q, Reddy R, Mukherjee M, Xu Y, Wonsey D, Lee LA, Dang CV: Deregulation of glucose transporter 1 and glycolytic gene expression by c-Myc. J Biol Chem 2000;275:21797-21800.

-8 Papandreou I, Cairns RA, Fontana L, Lim AL, Denko NC: HIF-1 mediates adaptation to hypoxia by actively downregulating mitochondrial oxygen consumption. Cell Metab 2006;3:187-197.

$\checkmark 9$ Robertson N, Potter C, Harris AL: Role of carbonic anhydrase IX in human tumor cell growth, survival, and invasion. Cancer Res 2004;64:6160-6165.

10 Shim H, Dolde C, Lewis BC, Wu CS, Dang G, Jungmann RA, Dalla-Favera R, Dang CV: c-Myc transactivation of LDH-A: implications for tumor metabolism and growth. Proc Natl Acad Sci USA 1997;94:6658-6663.
11 Welford SM, Bedogni B, Gradin K, Poellinger L, Broome Powell M, Giaccia AJ: HIFlalpha delays premature senescence through the activation of MIF. Genes Dev 2006;20:3366-3371.

12 Kato H, Takita J, Miyazaki T, Nakajima M, Fukai Y, Masuda N, Fukuchi M, Manda R, Ojima H, Tsukada K, Kuwano H: Glut-1 glucose transporter expression in esophageal squamous cell carcinoma is associated with tumor aggressiveness. Anticancer Res 2002; 22:2635-2639.

13 Mineta H, Miura K, Takebayashi S, Misawa K, Araki K, Misawa Y, Ueda Y: Prognostic value of glucose transporter 1 expression in patients with hypopharyngeal carcinoma. Anticancer Res 2002;22:3489-3494.

14 Shaw RJ: Glucose metabolism and cancer. Curr Opin Cell Biol 2006;18:598-608.

15 Tateishi U, Yamaguchi U, Seki K, Terauchi T, Arai Y, Hasegawa T: Glut-1 expression and enhanced glucose metabolism are associated with tumour grade in bone and soft tissue sarcomas: a prospective evaluation by $[18 \mathrm{~F}]$ fluorodeoxyglucose positron emission tomography. Eur J Nucl Med Mol Imaging 2006;33:683-691.

16 Oliver RJ, Woodwards RT, Sloan P, Thakker NS, Stratford IJ, Airley RE: Prognostic value of facilitative glucose transporter Glut-1 in oral squamous cell carcinomas treated by surgical resection: results of EORTC Translational Research Fund studies. Eur J Cancer 2004;40:503-507.

17 Younes M, Brown RW, Stephenson M, Gondo M, Cagle PT: Overexpression of Glut 1 and Glut3 in stage I nonsmall cell lung carcinoma is associated with poor survival. Cancer 1997;80:1046-1051.
18 Minami K, Saito Y, Imamura H, Okamura A: Prognostic significance of p53, Ki-67, VEGF and Glut- 1 in resected stage I adenocarcinoma of the lung. Lung Cancer 2002;38:51-57.

19 Schonberger J, Ruschoff J, Grimm D, Marienhagen J, Rummele P, Meyringer R, Kossmehl P, Hofstaedter F, Eilles C: Glucose transporter 1 gene expression is related to thyroid neoplasms with an unfavorable prognosis: an immunohistochemical study. Thyroid 2002;12:747-754.

20 Kawamura T, Kusakabe T, Sugino T, Watanabe K, Fukuda T, Nashimoto A, Honma K, Suzuki T: Expression of glucose transporter-1 in human gastric carcinoma: association with tumor aggressiveness, metastasis, and patient survival. Cancer 2001;92:634-641.

-21 Airley R, Loncaster J, Davidson S, Bromley M, Roberts S, Patterson A, Hunter R, Stratford I, West C: Glucose transporter glut-1 expression correlates with tumor hypoxia and predicts metastasis-free survival in advanced carcinoma of the cervix. Clin Cancer Res 2001;7:928-934.

22 Perou CM, Sorlie T, Eisen MB, van de Rijn M, Jeffrey SS, Rees CA, Pollack JR, Ross DT, Johnsen H, Akslen LA, Fluge O, Pergamenschikov A, Williams C, Zhu SX, Lonning PE, Borresen-Dale AL, Brown PO, Botstein D: Molecular portraits of human breast tumours. Nature 2000;406:747-752.

23 Dent R, Trudeau M, Pritchard KI, Hanna WM, Kahn HK, Sawka CA, Lickley LA, Rawlinson E, Sun P, Narod SA: Triple-negative breast cancer: clinical features and patterns of recurrence. Clin Cancer Res 2007;13: 4429-4434.

24 Brown RS, Wahl RL: Overexpression of Glut-1 glucose transporter in human breast cancer: an immunohistochemical study. Cancer 1993;72:2979-2985. 
-25 Ravazoula P, Batistatou A, Aletra C, Ladopoulos J, Kourounis G, Tzigounis B: Immunohistochemical expression of glucose transporter Glut1 and cyclin D1 in breast carcinomas with negative lymph nodes. Eur J Gynaecol Oncol 2003;24:544-546.

-26 Alo PL, Visca P, Botti C, Galati GM, Sebastiani V, Andreano T, Di Tondo U, Pizer ES: Immunohistochemical expression of human erythrocyte glucose transporter and fatty acid synthase in infiltrating breast carcinomas and adjacent typical/atypical hyperplastic or normal breast tissue. Am J Clin Pathol 2001;116:129-134.

-27 Grover-McKay M, Walsh SA, Seftor EA, Thomas PA, Hendrix MJ: Role for glucose transporter 1 protein in human breast cancer. Pathol Oncol Res 1998;4:115-120.

28 Stackhouse BL, Williams H, Berry P, Russell G, Thompson P, Winter JL, Kute T: Measurement of glut-1 expression using tissue microarrays to determine a race specific prognostic marker for breast cancer. Breast Cancer Res Treat 2005;93:247-253.

-29 Trastour C, Benizri E, Ettore F, Ramaioli A, Chamorey E, Pouyssegur J, Berra E: HIF-1alpha and CA IX staining in invasive breast carcinomas: prognosis and treatment outcome. Int J Cancer 2007;120:1451-1458.

-30 Chen CL, Chu JS, Su WC, Huang SC, Lee WY: Hypoxia and metabolic phenotypes during breast carcinogenesis: expression of HIF-1alpha, GLUT1, and CAIX. Virchows Arch 2010;457:53-61.

- 31 Chia SK, Wykoff CC, Watson PH, Han C, Leek RD, Pastorek J, Gatter KC, Ratcliffe P, Harris AL: Prognostic significance of a novel hypoxia-regulated marker, carbonic anhydrase IX, in invasive breast carcinoma. J Clin Oncol 2001;19:3660-3668.

-32 Hussain SA, Ganesan R, Reynolds G, Gross L, Stevens A, Pastorek J, Murray PG, Perunovic B, Anwar MS, Billingham L, James ND, Spooner D, Poole CJ, Rea DW, Palmer DH: Hypoxia-regulated carbonic anhydrase IX expression is associated with poor survival in patients with invasive breast cancer. $\mathrm{Br}$ J Cancer 2007;96:104-109.

-33 Pinheiro C, Sousa B, Albergaria A, Paredes J, Dufloth R, Vieira D, Schmitt F, Baltazar F: GLUT1 and CAIX expression profiles in breast cancer correlate with adverse prognostic factors and MCT1 overexpression. Histol Histopathol 2011;26:1279-1286.

-34 Kallioniemi OP, Holli K, Visakorpi T, Koivula T, Helin HH, Isola JJ: Association of c-erbB-2 protein over-expression with high rate of cell proliferation, increased risk of visceral metastasis and poor long-term survival in breast cancer. Int J Cancer 1991;49: 650-655.

35 Kim MJ, Ro JY, Ahn SH, Kim HH, Kim SB, Gong G: Clinicopathologic significance of the basal-like subtype of breast cancer: a comparison with hormone receptor and Her2/neu-overexpressing phenotypes. Hum Pathol 2006;37:1217-1226.
36 Livasy CA, Karaca G, Nanda R, Tretiakova MS, Olopade OI, Moore DT, Perou CM: Phenotypic evaluation of the basal-like subtype of invasive breast carcinoma. Mod Pathol 2006;19:264-271.

-37 Paik S, Hazan R, Fisher ER, Sass RE, Fisher B, Redmond C, Schlessinger J, Lippman ME, King CR: Pathologic findings from the National Surgical Adjuvant Breast and Bowel Project: prognostic significance of erbB-2 protein overexpression in primary breast cancer. J Clin Oncol 1990;8:103-112.

38 Rakha EA, Putti TC, Abd El-Rehim DM, Paish C, Green AR, Powe DG, Lee AH, Robertson JF, Ellis IO: Morphological and immunophenotypic analysis of breast carcinomas with basal and myoepithelial differentiation. J Pathol 2006;208:495-506.

39 Tsuda H, Takarabe T, Hasegawa F, Fukutomi T, Hirohashi S: Large, central acellular zones indicating myoepithelial tumor differentiation in high-grade invasive ductal carcinomas as markers of predisposition to lung and brain metastases. Am J Surg Pathol 2000;24: 197-202.

40 Tan EY, Yan M, Campo L, Han C, Takano E, Turley H, Candiloro I, Pezzella F, Gatter KC, Millar EK, O’Toole SA, McNeil CM, Crea P, Segara D, Sutherland RL, Harris AL, Fox SB: The key hypoxia regulated gene caix is upregulated in basal-like breast tumours and is associated with resistance to chemotherapy. Br J Cancer 2009;100:405-411.

-41 Elston CW, Ellis IO: Pathological prognostic factors in breast cancer. 1 . The value of histological grade in breast cancer: experience from a large study with long-term follow-up. Histopathology 1991;19:403-410.

42 Hammond ME, Hayes DF, Dowsett M, Allred DC, Hagerty KL, Badve S, Fitzgibbons PL, Francis G, Goldstein NS, Hayes M, Hicks DG, Lester S, Love R, Mangu PB, McShane L, Miller K, Osborne CK, Paik S, Perlmutter J, Rhodes A, Sasano H, Schwartz JN, Sweep FC, Taube S, Torlakovic EE, Valenstein P, Viale G, Visscher D, Wheeler T, Williams RB, Wittliff JL, Wolff AC: American Society of Clinical Oncology/College of American Pathologists guideline recommendations for immunohistochemical testing of estrogen and progesterone receptors in breast cancer. J Clin Oncol 2010;28:2784-2795.

43 Wolff AC, Hammond ME, Schwartz JN, Hagerty KL, Allred DC, Cote RJ, Dowsett M, Fitzgibbons PL, Hanna WM, Langer A, McShane LM, Paik S, Pegram MD, Perez EA, Press MF, Rhodes A, Sturgeon C, Taube SE, Tubbs R, Vance GH, van de Vijver M, Wheeler TM, Hayes DF: American Society of Clinical Oncology/College of American Pathologists guideline recommendations for human epidermal growth factor receptor 2 testing in breast cancer. J Clin Oncol 2007;25:118-145.
44 Kronblad A, Jirstrom K, Ryden L, Nordenskjold B, Landberg G: Hypoxia inducible factor-1alpha is a prognostic marker in premenopausal patients with intermediate to highly differentiated breast cancer but not a predictive marker for tamoxifen response. Int J Cancer 2006;118:2609-2616.

45 Kurebayashi J, Otsuki T, Moriya T, Sonoo H: Hypoxia reduces hormone responsiveness of human breast cancer cells. Jpn J Cancer Res 2001;92:1093-1101.

46 Laughner E, Taghavi P, Chiles K, Mahon PC, Semenza GL: HER2 (neu) signaling increases the rate of hypoxia-inducible factor lalpha (HIF-lalpha) synthesis: novel mechanism for HIF-1-mediated vascular endothelial growth factor expression. Mol Cell Biol 2001; 21:3995-4004.

-47 van der Groep P, Bouter A, Menko FH, van der Wall E, van Diest PJ: High frequency of HIF-1alpha overexpression in BRCA1 related breast cancer. Breast Cancer Res Treat 2008;111:475-480.

-48 Vleugel MM, Greijer AE, van der Wall E, van Diest PJ: Mutation analysis of the HIF-1alpha oxygen-dependent degradation domain in invasive breast cancer. Cancer Genet Cytogenet 2005; 163:168-172.

49 Vleugel MM, Bos R, Buerger H, van der Groep P, Saramaki OR, Visakorpi T, van der Wall E, van Diest PJ: No amplifications of hypoxia-inducible factor-1alpha gene in invasive breast cancer: a tissue microarray study. Cell Oncol 2004;26:347-351.

50 Xu XD, Yao C, Lin Y, Wang LP, Ma LL, Wang SM: The relationship between expression of macrophage migration inhibitory factor and prognosis of breast cancer (in Chinese). Zhonghua Yi Xue Za Zhi 2008;88:520-523.

51 Verjans E, Noetzel E, Bektas N, Schutz AK, Lue H, Lennartz B, Hartmann A, Dahl E, Bernhagen J: Dual role of macrophage migration inhibitory factor (MIF) in human breast cancer. BMC Cancer 2009;9:230.

52 Laudanski P, Koda M, Kozlowski L, Swiatecka J, Wojtukiewicz M, Sulkowski S, Wolczynski S: Expression of glucose transporter GLUT-1 and estrogen receptors ER-alpha and ER-beta in human breast cancer. Neoplasma 2004;51:164-168.

53 Sobhanifar S, Aquino-Parsons C, Stanbridge EJ, Olive P: Reduced expression of hypoxiainducible factor-1alpha in perinecrotic regions of solid tumors. Cancer Res 2005;65: 7259-7266.

54 Tomes L, Emberley E, Niu Y, Troup S, Pastorek J, Strange K, Harris A, Watson PH: Necrosis and hypoxia in invasive breast carcinoma. Breast Cancer Res Treat 2003;81:6169.

55 Bruckner BA, Ammini CV, Otal MP, Raizada MK, Stacpoole PW: Regulation of brain glucose transporters by glucose and oxygen deprivation. Metabolism 1999;48:422-431. 
56 Behrooz A, Ismail-Beigi F: Dual control of glut1 glucose transporter gene expression by hypoxia and by inhibition of oxidative phosphorylation. J Biol Chem 1997;272:55555562.

57 Kaluz S, Kaluzova M, Chrastina A, Olive PL, Pastorekova S, Pastorek J, Lerman MI, Stanbridge EJ: Lowered oxygen tension induces expression of the hypoxia marker MN/carbonic anhydrase IX in the absence of hypoxia-inducible factor 1 alpha stabilization: a role for phosphatidylinositol 3'-kinase. Cancer Res 2002;62:4469-4477.
Kopacek J, Barathova M, Dequiedt F, Sepelakova J, Kettmann R, Pastorek J, Pastorekova S: MAPK pathway contributes to densityand hypoxia-induced expression of the tumor-associated carbonic anhydrase IX. Biochim Biophys Acta 2005;1729:41-49.

59 Colpaert CG, Vermeulen PB, Fox SB, Harris AL, Dirix LY, Van Marck EA: The presence of a fibrotic focus in invasive breast carcinoma correlates with the expression of carbonic anhydrase IX and is a marker of hypoxia and poor prognosis. Breast Cancer Res Treat 2003;81:137-147.
60 Swietach P, Vaughan-Jones RD, Harris AL: Regulation of tumor $\mathrm{pH}$ and the role of carbonic anhydrase 9. Cancer Metastasis Rev 2007;26:299-310.

61 Morita T, Nagaki T, Fukuda I, Okumura K: Clastogenicity of low $\mathrm{pH}$ to various cultured mammalian cells. Mutat Res 1992;268:297305.

62 Perou CM: Molecular stratification of triplenegative breast cancers. Oncologist 2011; 16(suppl 1):61-70. 